Pujszo Ryszard, Zając Magdalena, Przybylski Grzegorz. The efficiency of the respiratory system of men at risk of social exclusion. $\begin{array}{lllllll}\text { Journal of Education, Health and } & \text { Sport. 2021;11(12):327-336. } & \text { eISSN }\end{array}$ http://dx.doi.org/10.12775/JEHS.2021.11.12.026

https://apcz.umk.pl/JEHS/article/view/JEHS.2021.11.12.026

https://zenodo.org/record/5805857

The journal has had 40 points in Ministry of Education and Science of Poland parametric evaluation. Annex to the announcement of the Minister of Education and Science of December 1, 2021. No. 32343. Has a Journal's Unique Identifier: 201159. Scientific disciplines assigned: Physical Culture Sciences (Field of Medical sciences and health sciences); Health Sciences (Field of Medical Sciences and Health Sciences).

Punkty Ministerialne z 2019 - aktualny rok 40 punktów. Zalącznik do komunikatu Ministra Edukacji i Nauki z dnia 1 grudnia 2021 r. Lp. 32343. Posiada Unikatowy Identyfikator Czasopisma: 201159. Przypisane dyscypliny naukowe:Nauki o kulturze fizycznej (Dziedzina nauk medycznych i nauk o zdrowiu); Nauki o zdrowiu (Dziedzina nauk medycznych i nauk o zdrowiu).

(1) The Authors 2021;

This article is published with open access at Licensee Open Journal Systems of Nicolaus Copernicus University in Torun, Poland

This article is published with open access at Licensee Open Journal Systems of Nicolaus Copernicus University in Torun, Poland
Open Access. This article is distributed under the terms of the Creative Commons Attribution Noncommercial License which permits any noncommercial use, distribution, and reproduction in any medium, provided the original author un (s) and source are credited. This is an open access article licensed under the terms of the Creative Commons Attribution Non commercial license Share alike.
(http://creativecommons.org//icenses/by-nc-sa/4.0/) which permits unrestricted, non commercial use, distribution and reproduction in any medium, provided the work is properly cited. The authors declare that there is no conflict of interests regarding the publication of this paper.

Received: 01.12.2021. Revised: 23.12.2021. Accepted: 27.12.2021.

\title{
The efficiency of the respiratory system of men at risk of social exclusion
}

\section{Ryszard Pujszo ${ }^{1}$, Magdalena Zając ${ }^{2}$, Grzegorz Przybylski ${ }^{3}$}

${ }^{1}$ Institute of Sport and Physical Culture, University of Economy, Bydgoszcz, Poland

${ }^{2}$ Department of Psychology, University of Kazimierz Wielki, Bydgoszcz, Poland

${ }^{3}$ Department of Respiratory Medicine and Tuberculosis, Nicolaus Copernicus University,

Collegium Medicum in Bydgoszcz, Poland

Magdalena Zając - ORCID : 0000-0002-8155-7614

Ryszard Pujszo - ORCID: 0000-0001-7000-8372

Grzegorz Przybylski - ORCID: 0000-0002-8324-163X

Corresponding author:

Ryszard Pujszo University of Economy Bydgoszcz

email: ryszard.pujszo@byd.pl

Key words: respiratory system, farming areas, social exclusion

\begin{abstract}
Background: Some part of the Polish society, after 1989, especially that coming from the remote farming areas - on the bankrupt State Agriculatural Farm could not cope in the new reality. Unemployment and the associated bad financial situation, poor housing conditions, and even homelessness, difficult access to medical care often generated the beginnings of social exclusion. Did those aspects also generate the impairment of the respiratory system or do the socio-demographic conditions demonstrate the relationship with the efficiency of the respiratory system?

Material and Methods: 210 people from Tuchola County at risk of social exclusion underwent spirometry testing. The spirometry results were demonstrated against a background of the same measurements carried out on the group of 95 people - physical labourers and white-collar workers of Kazimierz Wielki University. Basic socio-demographic conditions of people at risk of social exclusion were surveyed.

Results: Low efficiency of the respiratory system is a characteristic feature of people at risk of social exclusion. Social and living conditions (including housing conditions and
\end{abstract}


unemployment period) demonstrate vital relations with the efficiency of the respiratory system.

Conclusions: Poor social and living conditions and smoking of the examined people significantly change their chances of the standard spirometry results. However, good social and living conditions suggest that there is a possibility of the compensation of bad effects of smoking.

\section{Introduction}

The problem of the risk of social exclusion is not a new issue and it concerns people on all continents $[1,2,3,4]$. Initial reports concern times historically very distant $[5,6,7]$, while the very term "social exclusion" is attributed to Brian Barry and developed in France in the 70s of the $20^{\text {th }}$ century [8].

The reasons of this phenomenon are multidimensional: poverty, lifestyle, social stigma, physical or intellectual disability, ugliness, noticeable illness, political or religious views, conflicts with the law, alcoholism, old age and more contemporary reasons such as drug addiction, mobbing and many more $[9,10,11,12]$. However, it should be clearly emphasised that the aforementioned reasons might also be the results of social exclusion, which happened for some other reasons.

Research on the relations of this phenomenon with the possibility of the loss of both mental and physical health was carried out quite recently $[13,14,15,16,17]$.

In view of many concepts (including the Polish ones) the phenomenon of social exclusion generates addictional costs connected with public assistance, which mainly includes providing housing facilities, food supplies and basic medical care. These costs are borne by both nongovernmental organizations and national and local budgets to a large extent.

It is obvious that all social organizations are interested both in measurement and limitation of this phenomenon [17]. From the point of view of economics and health sciences it is obvious that prevention is much cheaper and more humane than treatment.

The human respiratory system is an important and well-studied human system which determines not only the biological existence of the human being but it also affects the physical functioning and the quality of life of a human being. It is also a system which causes the largest number of medical certificates of disability [18]. Reduced efficiency of the respiratory system is also responsible for the high mortality associated with lung diseases as well as with several diseases not related to the respiratory system, through pathogenic effects in various organs [19]. The authors quote only a few works out of hundreds describing the vital role of the efficiency of the respiratory system in the functioning of a human being in professional and private life $[20,21,22,23]$.

In Poland after the political transformation in 1989 and the massive collapse of State Agricultural Farms at the beginnings of 90s thousands of people from the rural areas bacame unemployed and many of them were left without any work prospects. Consequently, they were at risk of social exclusion as a loss of job causes poverty, housing problems/homelessness, difficult access to medical care, alcoholism and even criminality $[24,25,26]$.

The authors of this article share this view so they decided to examine the efficiency of the respiratory system of people at risk of social exclusion from the most rural county of the Kuyavian-Pomeranian Voivodeship i.e. Tuchola County [27].

The efficiency of the respiratory system of those people was compared with the efficiency of the respiratory system of avarage people (blue- and white-collar workers) leading sedentary 
lifestyle - not doing any forms of sports acivity. Data concerning life/ environment factors which could have the connection with the efficiency of the respiratory system of people at risk of social exclusion were collected and analyzed $[28,29,30]$.

\section{Material and methods}

The concept of social exclusion defined as: An individual is socially excluded if he or she is geographically resident in a society and he or she does not participate in the normal activities of citizens in that society [31]

Social Workers became acquainted with this definition and must decided, whether a person is at risk of social exclusion or already excluded.

When a person is trying to participate in social life (looking for a job, getting a new profession, training courses, etc.) were considered at risk of exclusion and directed to spirometry study at the Centre for Social Welfare.

210 people at risk of social exclusion underwent spirometry testing in 2014 . They came from the rural areas of Tuchola County (hereinafter - "people at risk") and 95 people from Kazimierz Wielki University not doing any forms of sports activity, leading sedentary lifestyle (herinafter - "the control group"). Altogether 305 people underwent testing.

All subjects were tested in terms of body weight and height on the basis of which BMI was determined.

The percentage of body fat was also determined by means of a BF -300, "OMRON". Then the subjects underwent spirometry testing by means of Microlab ML 3500 spirometer. These studies were carried out between 10-13 a.m. in a large and ventilated room with standard humidity and the temperature of $19-20^{\circ} \mathrm{C}$.

The following parameters were defined: vital capacity (VC), forced volume vital capacity (FVC), one second forced expiratory volume $\left(\mathrm{FEV}_{1}\right)$ and peak expiratory flow (PEF). Spirometry results of people at risk of social exclusion were presented and analyzed in numerical form and in, so called, due values expressed in percentage of norm according European Community of Steel and Coal European Respiratory Society (ECSC/ERS)

are still recommended by the Polish Society of Lung Diseases [32,33] adopting:

predicted value $<80 \%$ of standard value - low efficiency of the respiratory system

predicted value $\geq 80 \%$ of standard value - normal efficiency of the respiratory system

Threshold predicted value was adopted at the value of $80 \%$ bacause of the significantly low predicted values for people at risk of social exclusion for which avarage predicted values did not exceed $90 \%$ of the norm in any case (Table 3).

Data concerning living conditions of people at risk of social exclusion were collected in order to find possible relationships with the efficiency of the respiratory system (distance from a health care, unemployment period, smoking, housing conditions). The data were coded on the ordinal scale.

For economic and organizational reasons it was not possible to use physical indicators (for example cotinine level) or questionnaires like Fagerstrom test in order to determine the degree of smoking so only individual declarations were used. Statistical processing was made using Statistica 10.0 (parametric $\mathrm{f}$-test for variances, parametric t-test for differences, the differences meaningful on the level $p<0,05$ ).

In order to find the relationship between spirometry results and selected social conditions in subjects at risk of social exclusion Spearman correlation coefficients were calculated and logistic regression was performed. The results are shown in Tables 1-6. 
The study protocol was accepted by the Ethics Committee of Ludwik Rydygier Collegium Medicum, Nicolaus Copernicus University, in November 2013 (KB 558/2013). and a written informed consent was obtained from each participant.

\section{Results}

Anthropometric data of all groups are presented in Table 1, and the spirometry test results are shown in Table 2.

Table 1. Basic anthropometric data of people (age, body weight, body height, and slenderness ratio - BMI) in both groups.

\begin{tabular}{|c|c|c|c|c|c|c|c|c|}
\hline Group & $\begin{array}{l}\text { Age } \\
\text { (years) }\end{array}$ & $\begin{array}{l}\text { Range } \\
\text { (years) }\end{array}$ & $\begin{array}{l}\text { Body } \\
\text { weight } \\
(\mathrm{kg})\end{array}$ & $\begin{array}{l}\text { Range } \\
(\mathrm{kg})\end{array}$ & $\begin{array}{l}\text { Body height } \\
\text { (m) }\end{array}$ & $\begin{array}{l}\text { Range } \\
(\mathrm{m})\end{array}$ & $\begin{array}{l}\text { BMI } \\
\left(\mathrm{kg} / \mathrm{m}^{2}\right)\end{array}$ & $\begin{array}{l}\text { Range } \\
\left(\mathrm{kg} / \mathrm{m}^{2}\right)\end{array}$ \\
\hline $\begin{array}{l}\text { Group at } \\
\text { risk }\end{array}$ & $\begin{array}{l}46,1^{*} \\
\pm \\
14,4\end{array}$ & $19-66$ & $\begin{array}{l}78,6^{*} \\
\pm \\
14,6\end{array}$ & $48,5-141$ & $\begin{array}{l}1,73^{*} \\
\pm \\
0,06\end{array}$ & $\begin{array}{l}1,61 \\
- \\
1,90\end{array}$ & $\begin{array}{l}26,1 \\
\pm \\
4,3\end{array}$ & $\begin{array}{l}17,7 \\
- \\
44,1\end{array}$ \\
\hline $\begin{array}{l}\text { Control } \\
\text { group }\end{array}$ & $\begin{array}{l}41,3^{*} \\
\pm \\
13,6\end{array}$ & $\begin{array}{l}19 \\
- \\
62,5\end{array}$ & $\begin{array}{l}83,2^{*} \\
\pm \\
13,0\end{array}$ & $\begin{array}{l}62,5 \\
-120,5\end{array}$ & $\begin{array}{l}1,76^{*} \\
\pm \\
0,06\end{array}$ & $\begin{array}{l}1,64 \\
- \\
1,98\end{array}$ & $\begin{array}{l}26,7 \\
\pm \\
3,2\end{array}$ & $\begin{array}{l}21,1 \\
- \\
36,4\end{array}$ \\
\hline
\end{tabular}

* - statistically significant differences in these same columns in the table at $p<0,05$

Statistically significant differences in age, weight and body height of the compared groups were reported. There was no significant differnce in BMI slenderness ratio.

Table 2. Average spirometry tests figures (VC, FVC, FEV1 and PEF) and percentage of body fat in both groups.

\begin{tabular}{|c|c|c|c|c|c|c|c|c|c|c|}
\hline Group & $\begin{array}{l}\text { \%of body } \\
\text { fat. }\end{array}$ & Range & $\begin{array}{l}\mathrm{VC} \\
\left(\mathrm{dm}^{3}\right)\end{array}$ & $\begin{array}{l}\text { Range } \\
\left(\mathrm{dm}^{3}\right)\end{array}$ & $\begin{array}{l}\text { FVC } \\
\left(\mathrm{dm}^{3}\right)\end{array}$ & $\begin{array}{l}\text { Range } \\
\left(\mathrm{dm}^{3}\right)\end{array}$ & $\begin{array}{l}\text { FEV } 1 \\
\left(\mathrm{dm}^{3}\right)\end{array}$ & $\begin{array}{l}\text { Range } \\
\left(\mathrm{dm}^{3}\right)\end{array}$ & $\left(\mathrm{dm}^{3} / \mathrm{min}\right)$ & Range \\
\hline Group & $21,8^{*}$ & 16,6 & $4,12^{*}$ & 2,7 & $3,26^{*}$ & 2.1 & $2,98^{*}$ & 1,69 & $440,1^{*}$ & 244,0 \\
\hline \multirow[t]{2}{*}{ at risk } & \pm & - & \pm & - & \pm & - & \pm & - & \pm & - \\
\hline & 4,2 & 36,1 & 0,81 & 6,3 & 0,73 & 6,0 & 0,63 & 5,30 & 87,9 & 671,0 \\
\hline \multirow{3}{*}{$\begin{array}{l}\text { Control } \\
\text { group }\end{array}$} & $22,4^{*}$ & 6,5 & $4,45^{*}$ & 2,85 & $4,29^{*}$ & 2,90 & $3,65^{*}$ & 2,10 & $530,1 *$ & 385,0 \\
\hline & \pm & - & \pm & - & \pm & - & \pm & - & \pm & - \\
\hline & 6,3 & 35,3 & 0,63 & 5,86 & 0,70 & 5,93 & 0,58 & 5,47 & 69,8 & 689,0 \\
\hline
\end{tabular}

* - statistically significant differences in these same columns in the table at $p<0,05$

In all spirometry parameters (VC, FVC, FEV1,PEF) statistically significant differences between values in both groups were reported. The significant difference concerned also the percentage of body fat.

For each group average predicted (normative) values were calculated and they were expressed in a percentage of norm for each spirometry measurement (VC, FVC, FEV1 and PEF). 
Average predicted values are presented in Table 3.

Table 3. Average predicted values (expressed in \% of norm) of spirometry tests VC, FVC, FEV1 and PEF in both groups.

\begin{tabular}{|c|c|c|c|c|c|c|c|c|}
\hline Group & $\begin{array}{l}\mathrm{VC} \\
(\%)\end{array}$ & $\begin{array}{l}\text { Range } \\
(\%)\end{array}$ & $\begin{array}{l}\text { FVC } \\
(\%)\end{array}$ & $\begin{array}{l}\text { Range } \\
(\%)\end{array}$ & $\begin{array}{l}\text { FEV1 } \\
(\%)\end{array}$ & $\begin{array}{l}\text { Range } \\
(\%)\end{array}$ & $\begin{array}{l}\text { PEF } \\
(\%)\end{array}$ & $\begin{array}{l}\text { Range } \\
(\%)\end{array}$ \\
\hline \multirow[t]{3}{*}{ Group at risk } & $88,2^{*}$ & 66,1 & $73,5^{*}$ & 43,9 & $82,6^{*}$ & 51,9 & $83,4^{*}$ & 50,5 \\
\hline & \pm & - & \pm & - & \pm & - & \pm & - \\
\hline & 11,5 & 126,1 & 11,8 & 113,9 & 11,7 & 119,8 & 13,6 & 116,5 \\
\hline \multirow[t]{3}{*}{ Control group } & $90,1^{*}$ & 70,9 & $90,6^{*}$ & 72,3 & $94,7 *$ & 67,3 & $96,6^{*}$ & 75,2 \\
\hline & \pm & - & \pm & - & \pm & - & \pm & - \\
\hline & 9,3 & 114,3 & 9,8 & 113,1 & 12,2 & 130,9 & 10,9 & 124,1 \\
\hline
\end{tabular}

* - statistically significant differences in these same columns in the table at $p<0,05$

All average predicted values expressed as percentage standards differ significantly in the case of both groups. Higher - favorable results were obtained in the control group.

Predicted values obtained in the group at risk of social exclusion are significantly lowered. Further analysis of spirometry results concerned exclusively predicted spirometry values.

The relation between variables (Spearman rank correlation) taken into account in the measurement and spirometry parameters was checked.

The strength and the direction of the relation are presented in Table 4.

Table 4. Spearman correlation coefficients for spirometry variables, and socio-demographic conditions of subjects from the risk group.

\begin{tabular}{llll}
\hline & \multicolumn{1}{c}{$\mathrm{R}$ - Spearman } & \multicolumn{1}{c}{$\mathrm{t}(\mathrm{N}-2)$} & $\mathrm{p}$ \\
\hline smoking \& VC & $-0,225788$ & $-3,3427$ & 0,000984 \\
\hline smoking \& FVC & $-0,599521$ & $-10,8032$ & 0,00001 \\
\hline smoking \& FEV1 & $-0,539552$ & $-9,2422$ & 0,00001 \\
\hline smoking \& PEF & $-0,636058$ & $-11,8881$ & 0,00001 \\
\hline unemployment \& VC & $-0,375244$ & $-5,8385$ & 0,00001 \\
\hline unemployment. \& FVC & $-0,705435$ & $-14,3542$ & 0,00001 \\
\hline unemployment \& FEV1 & $-0,651435$ & $-12,3831$ & 0,00001 \\
\hline unemployment \& PEF & $-0,614147$ & $-11,2233$ & 0,00001 \\
\hline housing conditions \& VC & $-0,258002$ & $-3,8513$ & 0,000156 \\
\hline housing conditions \& FVC & $-0,633368$ & $-11,8040$ & 0,00001 \\
\hline housing conditions \& FEV1 & $-0,535933$ & $-9,1551$ & 0,00001 \\
\hline housing conditions \& PEF & $-0,463873$ & $-7,5517$ & 0,00001 \\
\hline distance from health care \& VC & 0,105459 & 1,5295 & 0,127666 \\
\hline distance from health care \& FVC & 0,292433 & 4,4103 & 0,000017 \\
\hline distance from health care \& FEV1 & 0,268529 & 4,0205 & 0,000081 \\
\hline distance from health care \& PEF & $-0,100119$ & $-1,4512$ & 0,148222 \\
\hline
\end{tabular}

Poor housing conditions, unemployment and smoking significantly lowered the spirometry parametres. The strength of the relationship maintained at the value of medium/average to the 
high values. The lack of the significance of the relationship was observed for the distance from health care and VC and PEF parameters. For the remaining parameters (FVC, FEV1) the relationship was weak on the opposite direction in relation to the other variables - the higher distance from health care favoured the higher values FVC and FEV1.

On account of the different operation of the variables, the analysis of logistic regression of socio-demographic factors and smoking in a group at risk of social exclusion was conducted. In the analysis, a due indicator as $\mathrm{x} \geq 80 \%$ of the norm was adopted as normal and the regression was performed taking into account all the indicators tested separately and simultaneously.

Parameter determination is separately shown in Table 5.

Table 5. Determination VC, FVC, FEV1, PEF (predicted values) - univariate analysis

\begin{tabular}{|c|c|c|c|c|c|c|c|c|}
\hline & $\mathrm{VC}$ & & $\mathrm{FVC}$ & & FEV1 & & PEF & \\
\hline & $\mathrm{OR}(95 \% \mathrm{CI})$ & $\begin{array}{l}\mathrm{p}- \\
\text { value }\end{array}$ & $\mathrm{OR}(95 \% \mathrm{CI})$ & $\begin{array}{l}\mathrm{p}- \\
\text { value }\end{array}$ & $\mathrm{OR}(95 \% \mathrm{CI})$ & $\begin{array}{l}\mathrm{p}- \\
\text { value }\end{array}$ & OR(95\%CI) & $\begin{array}{l}\mathrm{p}- \\
\text { value }\end{array}$ \\
\hline $\begin{array}{l}\text { Unemploy } \\
\text { ment }\end{array}$ & $\begin{array}{l}2,05(1,37- \\
3,07)\end{array}$ & 0,001 & $\begin{array}{l}2,97 \quad(2,01- \\
4,37)\end{array}$ & $\begin{array}{l}0,00 \\
01 \\
\end{array}$ & 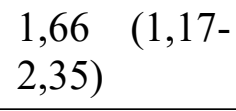 & $\begin{array}{l}0,000 \\
7\end{array}$ & $\begin{array}{l}2,89 \quad(1,87- \\
4,48)\end{array}$ & $\begin{array}{l}0,000 \\
1\end{array}$ \\
\hline $\begin{array}{l}\text { Housing } \\
\text { conditions }\end{array}$ & $\begin{array}{l}1,57 \quad(1,04- \\
2,39)\end{array}$ & 0,030 & $\begin{array}{l}5,17 \quad(2,77- \\
9,69)\end{array}$ & $\begin{array}{l}0,00 \\
01\end{array}$ & $\begin{array}{l}3,44 \\
5,44)\end{array}$ & $\begin{array}{l}0,000 \\
1\end{array}$ & $\begin{array}{l}3,09 \\
4,87)\end{array}$ & $\begin{array}{l}0,000 \\
1\end{array}$ \\
\hline $\begin{array}{l}\text { Distance } \\
\text { from health } \\
\text { care }\end{array}$ & $\begin{array}{l}0,82 \quad(0,52- \\
1,29)\end{array}$ & n.s & $\begin{array}{l}0,60(0,39- \\
0,90)\end{array}$ & $\begin{array}{l}0,02 \\
00\end{array}$ & $\begin{array}{l}0,729(0,476 \\
-1,11)\end{array}$ & $\begin{array}{l}0,000 \\
0\end{array}$ & $\begin{array}{l}3,08 \\
4,86)\end{array} \quad(1,95-$ & $\begin{array}{l}0,000 \\
1\end{array}$ \\
\hline Smoking & $\begin{array}{l}1,16(0,81- \\
1,65)\end{array}$ & n.s. & $\begin{array}{l}1,80 \quad(1,26- \\
2,58)\end{array}$ & $\begin{array}{l}0,00 \\
10\end{array}$ & $\begin{array}{l}1,71(1,20- \\
2,42)\end{array}$ & $\begin{array}{l}0,002 \\
0\end{array}$ & $\begin{array}{l}3,91 \quad(2,36- \\
6,48)\end{array}$ & $\begin{array}{l}0,000 \\
0\end{array}$ \\
\hline
\end{tabular}

The chance for the correct score of the predicted value turned out to be the smallest in smokers (from a reduction of $16 \%$ for $\mathrm{VC}$, for PEF even for four times). The OR obtained for the distance from health care suggests an opposite effect in relation to the other factors for parameters (VC, FVC and FEV1), hence it was necessary to perform the overall analysis shown in Table 6. 
Table 6. Determination VC, FVC, FEV1, PEF (predicted values) - overall analysis

\begin{tabular}{|c|c|c|c|c|c|c|c|c|}
\hline & \multicolumn{2}{|l|}{$\mathrm{VC}$} & \multicolumn{2}{|l|}{ FVC } & \multicolumn{2}{|c|}{ FEV1 } & \multicolumn{2}{|l|}{ PEF } \\
\hline & $\mathrm{OR}(95 \% \mathrm{CI})$ & $\begin{array}{l}\mathrm{p}- \\
\text { value }\end{array}$ & $\mathrm{OR}(95 \% \mathrm{CI})$ & $\begin{array}{l}\mathrm{p}- \\
\text { value }\end{array}$ & $\mathrm{OR}(95 \% \mathrm{CI})$ & $\begin{array}{l}\mathrm{p}- \\
\text { value }\end{array}$ & $\mathrm{OR}(95 \% \mathrm{CI})$ & $\begin{array}{l}\mathrm{p}- \\
\text { value }\end{array}$ \\
\hline $\begin{array}{l}\text { Unemploy } \\
\text { ment }\end{array}$ & $\begin{array}{l}1,492(0,786 \\
-2,832)\end{array}$ & n.s. & $\begin{array}{l}2,001 \\
(1,197- \\
3,340)\end{array}$ & 0,01 & $\begin{array}{l}2,364(1,429 \\
-3,912)\end{array}$ & $\begin{array}{l}0,000 \\
7\end{array}$ & $\begin{array}{l}1,965 \\
(1,145- \\
3,376)\end{array}$ & 0,02 \\
\hline $\begin{array}{l}\text { Housing } \\
\text { conditions }\end{array}$ & $\begin{array}{l}2,09(1,089- \\
4,011)\end{array}$ & 0,02 & $\begin{array}{l}4,794 \\
(2,487- \\
9,243)\end{array}$ & 0,01 & $\begin{array}{l}2,408(1,356 \\
-4,277)\end{array}$ & $\begin{array}{l}0,002 \\
0\end{array}$ & $\begin{array}{l}1,213(0,703 \\
-2,094)\end{array}$ & n.s. \\
\hline $\begin{array}{l}\text { Distance } \\
\text { from health } \\
\text { care }\end{array}$ & $\begin{array}{l}1,02(0,598- \\
1,758)\end{array}$ & n.s. & $\begin{array}{l}0,749(0,453- \\
1,237)\end{array}$ & n.s. & $\begin{array}{l}0,852(0,535 \\
-1,355)\end{array}$ & n.s. & $\begin{array}{l}3,746(2,025 \\
-6,929)\end{array}$ & $\begin{array}{l}0,000 \\
1\end{array}$ \\
\hline Smoking & $\begin{array}{l}0,532 \\
(0,282- \\
1,003)\end{array}$ & n.s. & $\begin{array}{l}0,695(0,399- \\
1,209)\end{array}$ & n.s. & $\begin{array}{l}0,612(0,360 \\
-1,042)\end{array}$ & n.s. & $\begin{array}{l}1,807(1,062 \\
-3,074)\end{array}$ & 0,03 \\
\hline
\end{tabular}

On the basis of the odds ratios it can be stated that housing conditions significantly lower the chance for the correct predicted values for VC, FVC and FEV1. If the housing conditions are poor, the odds for the correct predicted value for $\mathrm{VC}$ are lowered twice, for the correct predicted value for FVC are lowered five times and for the correct predicted value for FEV1 for about 1,5 times. For VC parameter it was the only significant factor explaining variation. Lack of employment determined the FVC: increasing twice the chance of the results below the correct normative value, 2.3 - fold increased chance for FEV1 below the correct result of the due predicted and almost twice reduced the chance of a correct result of the predicted value for the PEF.

Smoking diversified the chance for the correct result of the predicted value only in the case of the PEF - this chance was $80 \%$ higher in non-smokers. Distance from the health care worked in a different manner than the remaining factors. It turned out to significantly modify the chance of obtaining the correct predicted value for the PEF. Higher distance from health care increased even 3.7 -fold the frequency of obtaining the correct predicted value for the PEF among the subjects - the authors of the article left this result without comment as unexpected and demanding separate studies.

\section{Discussion}

The percentage of body fat in the group of people at risk of social exclusion similar to the value of the percentage of body fat in the control group and the lack of the significant differences in the BMI factor suggest the stable nutritional status of people at risk of social exclusion. In this case there is no phenomenon of pathological malnutrition.

The authors of the article note that although the BMI might be misleading in the assessment of malnutrition, however, in combination with body fat it brings reliable assessment if malnutrition occurs [34]. 
The lower absolute values in spirometry as well as significantly lower predicted values obtained by people from the group at risk of social exclusion are consistent with other results of spirometry testing obtained from so-called isolated social groups. [35].

The applied procedure of logistic regression using a quasi-Newton method allowed to estimate which parameters most affected the occurrence of the impairment of the respiratory system of people at risk of social exclusion.

The univariate analysis indicates that smoking strongly conditions the spirometry results lowering the due values (even four times in the case of PEF). The overall analysis of all sociodemographic conditions indicates that the highest impact on the spirometry parameters had such factors as unemployment and poor housing conditions, which lower the chance of correct predicted value by 2.5 -fold in the group of people at risk of social exclusion. Similar relations were presented by the authors studying the phenomenon of unemployment among people with tuberculosis [36].

The significant impact of the housing conditions on the efficiency of the respiratory system was also repeatedly indicated, but mostly the analysis concerned poor housing conditions $[37,38,39]$. The authors of the article have not found any analysis in the literature concerning positive impact of good housing conditions on the efficiency of the respiratory system. The distance from the health care caused better spirometry results, but apart from PEF the chance of the correct predicted value in the subjects living far from medical care significantly rose. This result should be separately analyzed taking into account that this variable assumes the character of a mediator with the function of a buffer for other factors.

This study has revealed one significant and interesting observation: there was a small relationship between smoking and the correct due predicted in spirometry in the subjects at risk of social exclusion.

In multivariate analysis - only for the PEF, smoking decreased by $80 \%$ the chance of correct predicted value. It should be noted that other reports also indicated the lack of significant associations between smoking and the treatment of tuberculosis [40].

The results suggest that better social and living conditions of people at risk of social exclusion can act as a compensating factor against further lowering of the predicted values of the spirometry parameters. Importantly, this trend however, applies to people whose aerobic capacity remains at the low level.

However, one should take into account that the study relied on the declaration of the subjects and it was not possible to use other indicators. The subjects, by virtue of their social status, might be more likely to be prone to social approval, hence caution should be exercised in interpreting the data.

\section{Conclusions}

1. The people at risk of social exclusion significantly differ from the control group in terms of the level of spirometry parameters. People who are not at risk of social exclusion have a higher efficiency of the respiratory system.

2. Living conditions (unemployment, housing conditions, smoking, distance to a medical facility) of the subjects significantly change the chances of obtaining correct predicted values of spirometry results. Persistent unemployment, poor living conditions lower the predicted values of spirometry results and constitute a mediator bufforing a negative impact of other factors.

3. Smoking, acting individually, lowers the chance of correct predicted values in spirometry. In combination with other socio-demographic factors it lowers the chance of correct predicted value only of the PEF. It allows to suggest that socio-demographic 
factors play a balancing role in relation to the impact of smoking on the results of spirometry (VC, FVC, FEV1) in subjects with the reduced efficiency of the respiratory system.

\section{References}

1. Cousins C: Social exclusion in Europe: paradigms of social disadvantage in Germany, Spain, Sweden and the United Kingdom. Policy \& Politics, 1998; 26(2): 127-146.

2. Geremek B: People on the society margins in medieval Paris in XIV-XV century. Ed: PTTPN, 1971; 281 [in Polish]

3. Hammer T: Youth unemployment and social exclusion in Europe: a comparative study. Policy Press Bristol, England, 2003.

4. Phipps S, Curtis L: The social exclusion of children in North America. Dalhousie University, Halifax, 2001.

5. Czarnowski S: People expendable in the service of violence. Works, 1935; (2):186 [in Polish]

6. Kamler M: World of crime in Poland in XVI and XVII centurie. Ed: Scientific Publisherse PWN, 1991;196 [in Polish]

7. Zaremska H: The outlaws of Medieval Europe. Semper, 1993;172 [inPolishh]

8. Barata, P: Social Exclusion in Europe: Survey of Literature. Mimeo. Toronto: Laidlaw Foundation, 2000.

9. Brzozowski TT: Globalization and social exclusion. Ethical and cultural genesis of the marginalization process. Przedsiębiorczość-Edukacja, 2011; 7: 173-1186 [in Polish]

10.Cęcelek G: Pauperization of the family and the child's risk of social exclusion. Mazowieckie Studia Humanistyczne, 2008; 12/1,2: 215-223 [in Polish]

11. Małyska A: Foreclosure withdrawal or coexistence? About the place of old age in the modern world. Edukacja Dorosłych, 2012; 1(66): 53-61 [in Polish]

12. Sendyk M, Ilnicka RM: The family of modified internal structure as a source of social exclusion of young people. Rocznik Lubuski, 2013; 39(2): 37-47 [in Polish]

13. Labonte R: Social inclusion/exclusion: dancing the dialectic. Health Promotion International, 2004; 19(1): 115-121.

14. Morgan C, Burns T, Fitzpatrick R, Pinfold V, Priebe S: Social exclusion and mental health Conceptual and methodological review. Br J Psychiatry. 2007;191(6): 477-483.

15. Pospiszyl I: Social pathologies - resocialization. Ed: Scientific Publisherse PWN, 2008; 355 [in Polish]

16. Unit SE, Britain G: Preventing social exclusion. London. Cabinet Office, 2001

17. Włodarczyk C: Health and social exclusion. The problems of the European health policy. Problemy Polityki Społecznej, 1999;1: 59-88 [in Polish]

18. Grabek-Kozera J: Economic activity of the disabled. Materials from the conference, "Dator laboris - employer". Norbrtinum, 2007;1: 37-70 [in Polish]

19. Beaty TH, Cohen BH, Newill CA, Menkes HA, Diamond EL, Chen CJ Impaired pulmonary function as a risk factor for mortality, Am J Epidemiol. 1982;116(1):102-13.

20. Kłossowski M, Paszkiewicz K, Mazurek, K: Evaluating the effectiveness of functional respiratory candidates for military aviation. Pol Przegl Med Lotn, 1999;3: 217-224 [in Polish]

21. Kozak-Szkopek E, Galus K: The effect of rehabilitation on psychomotor performance in the elderly.Gerontologia Polska, 2009;17(2): 79-84 [in Polish]

22. Najmiec A: Professions difficult and dangerous. In the shadow of the wings - the aviation mechanic . Bezpieczeństwo Pracy: nauka i praktyka, 2006; 5: 4-7 [in Polish] 
23. Nonn-Wasztan S: The health of women and men in terms of rehabilitation methods in the water. Nowiny Lekarskie, 2012; 81(4): 404-411 [in Polish]

24. Śmilgin M: Individual and social effects of unemployment on the background of globalization. Nierówności Społeczne a Wzrost Gospodarczy, Ed: Uniwersytet Rzeszowski, 2006; 8: 423-434 [in Polish]

25. Tarkowska E: Polish calculates poverty. Więź, 2009; 04 (606): 90-100 [in Polih]

26. Sztaudynger JJ, Sztaudynger M: Econometric models of crime. Ruch prawniczy, ekonomiczny i socjologiczny, 2003; 65(3), 127-143 [in Polish]

27. BIP (Public Information Bulletin) - powiat Tucholski 2014/2015 [inPolih] [avaiable]; http://bippowiat.tuchola.pl/

28. Dębski M: The socio-demographic portrait of the homeless community-continuity or change? Methodological problems of the study of homelessness in the Pomeranian Region in 2001-2005. Ed: M. Dębski, K. Stachura: The faces of Homelessness 2008;137328 [in Polish]

29. Gromadecka-Sutkiewicz M, Kłos J, Adamek R, Żysnarska M, Kara I.: Tobacco smoking and drinking alcohol among the unemployed. Przegląd Lekarski, 2012, 69(10): 973977[in Polish]

30. Rydzyński K, Michalak J: Economic changes and their significance for occupational medicine and hygiene. Medycyna Pracy, 2002; 53(1): 5-13 [in Polish]

31. Burchardt, T., J. Le Grand, and D. Piachaud (1999) "Social exclusion in Britain 19911995" Social Policy and Administration, 33(3): 227-244.

32. Quanjer PH, Tammeling GJ, Cotes JE, Pedersen OF, Peslin R, Yernault JC. Lung volumes and forced ventilatory flows. Report Working Party Standardization of Lung Function Tests, European Community for Steel and Coal. Official Statement of the European Respiratory Society. Eur. Respir. J. Suppl. 1993; 16: 5-40.

33. Boros P, Franczuk M, Wesołowski S: Principles of interpretation of the results of spirometry. Pneumonol. Alergol. Pol. 2006; 74 (supl. 1): 21-38.

34. Wojskowicz A, Wojszel ZB, Gułaj E, Wojskowicz P, Kasiukiewicz A, Klimiuk KE: Obesity and risk of malnutrition in advanced old age", Geriatria, 2013; 7: 51-55 [in Polish]

35. Cianciara D, Nowicka J, Sitarek M: Support of the Roma community in Poland. Probl Hig Epidemiol, 2012; 93(1): 189-194 [in Polish]

36. Przybylski G, Dąbrowska A, Pilaczyńska-Cemel M, Krawiecka D. Unemployment in TB Patients-Ten-Year Observation at Regional Center of Pulmonology in Bydgoszcz, Poland. Med Sci Monit., 2014; 20: 2125-2131.

37. Antczak A, Górski P: Eicosanoids in exhaled breath condensate in asthma patients. Pneumonol Alergol Pol. 2004; 72(7-8): 296-307 [in Polish]

38. Wiszniewska M, Świerczyńska-Machura D, Pałczyński C, et al.: Uczulenie na grzyby wśród konserwatorów zabytków - występowanie, czynniki ryzyka i obraz kliniczny. Medycyna Pracy, 2010; 61(2): 133-141 [in Polish]

39. Zielonka TM: Rola lekarzy rodzinnych w wykrywaniu chorób układu oddechowego część II. [In]: Forum Medycyny Rodzinnej 2011; 5(6): 468-474 [in Polish]

40. Przybylski G, Dąbrowska A, Trzcińska H: Alcoholism and other socio-demographic risk factors for adverse TB-drug reactions and unsuccessful tuberculosis treatment - data from ten years' observation at the Regional Centre of Pulmonology, Bydgoszcz, Poland. Med Sci Monit., 2014; 20: 444-453. 